\title{
Mechanism and pharmacological rescue of berberine-induced hERG channel deficiency [Corrigendum]
}

\author{
Yan M, Zhang KP, Shi YH, Feng LF, Lv L, Li BX. Drug \\ Des Devel Ther. 2015 Oct 22;9:5737-5747.
}

On page 5742, Figure 3C, an incorrect Western blot image is shown. The correct Western blot image for Figure $3 \mathrm{C}$ is shown here:

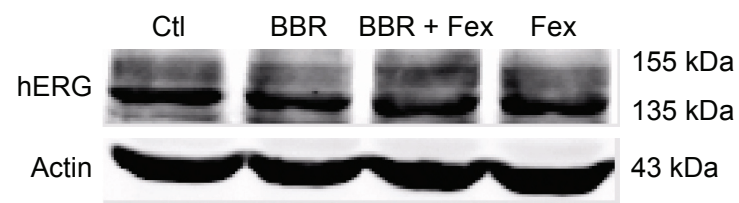

\section{Publish your work in this journal}

Drug Design, Development and Therapy is an international, peerreviewed open-access journal that spans the spectrum of drug design and development through to clinical applications. Clinical outcomes, patient safety, and programs for the development and effective, safe, and sustained use of medicines are the features of the journal, which has also been accepted for indexing on PubMed Central. The manuscript management system is completely online and includes a very quick and fair peer-review system, which is all easy to use. Visit http://www.dovepress.com/testimonials.php to read real quotes from published authors. 